\title{
Técnicas y métodos más adecuados para la identificación del cemento aluminoso y de cemento de base portland en hormigones
}

\author{
The most suitable techiniques and methods to identify \\ high alumina cement and based portland cement \\ in concretes
}

M. T. BLANCO, F. PUERTAS y T. VAZQUEZ, Drs. en Ciencias Químicas

ICCET/CSIC

A. DE LA FUEṄTE, Lcdo. en Ciencias Químicas

CTCRH (")

ESPAÑA

Fecha de recepción: 11-XII-92.

\section{RESUMEN}

Se indican las técnicas y se explican las metodologías más adecuadas para determinar la naturaleza del conglomerante aluminoso en hormigones. Estos métodos son:

a) Determinación del Módulo Silícico, a través de Análisis Químico de la muestra problema, al considerar la acusada diferencia de aquel valor en hormigones de cemento portland, respecto a hormigones de cemento aluminoso.

b) Difracción de Rayos $X$. Se considera la técnica idónea. Se dan en el presente trabajo las principales líneas de difracción de los compuestos característicos de los cementos hidratados, portland y aluminoso.

Como métodos complementarios y de utilidad limitada se estudia el ATD y el TG. Se proponen las temperaturas más significativas de los compuestos hidratados de aquellos cementos, a través de lo cual se puede deducir la presencia de uno u otro tipo de cemento.

Se hace una valoración del método de la "oxina", significando el alcance limitado del mismo. Igualmente se describe el color como indicador de gran interés práctico en la determinación del cemento aluminoso. Así como un comentario documentado sobre el significado de la presencia de diferentes polimorfías del $\mathrm{CaCO}_{3}$ en los hormigones de cemento portland y de cemento aluminoso.

\section{$S U M M A R Y$}

Instrumental techniques are indicated and the most adequated methodologies for determining the nature of the binder in concretes are explained. These methods are:

a) Determination of the Silicic Moduli through chemical analysis of the sample. This test reveals very different values between cement portland based concrete and high alumina cement based concretes.

b) X-ray diffraction. It is considered as the best method. In the present paper the main diffraction lines corresponding to the components of hydrated portland cement and high alumina cement, are given.

As complementary methods having as limited use, DTA and $T G$ are studied. The most significative changes of the hydrated phases of both cements when heated are shown.

\begin{abstract}
A valoration of the Oxine test is also done as well as a description of using the characteristic colour of the high alumina cement as a practical indicator for determining its presence in concretes. Finally, comments on the significance of the presence of different $\mathrm{CaCO}_{3}$ polymorhisms in portland cement concrete and high alumina cement concretete are also done.
\end{abstract}

(*) Centre Tècnic i de Cooperació per a la Rehabilitació d'Habitatges. Generalitat de Catalunya. Barcelona. 


\section{INTRODUCCIÓN}

Ante una anomalía hallada en un hormigón el primer interrogante que surge es el de conocer el tipo de conglomerante que posee. Para su resolución, en la actualidad, se están utilizando métodos y técnicas cuyo alcance, fiabilidad y adecuación al fin es objeto de polémica entre los técnicos.

En el presente trabajo se da cuenta de las técnicas más adecuadas para la identificación de la naturaleza del conglomerante, utilizado en la elaboración de un hormigón, y se proponen las metodologías de ensayo e interpretación.

\section{MÉTODOS MÁS ADECUADOS PARA CONOCER LA NATURALEZA DEL CEMENTO (PORTLAND O ALUMINOSO) EN UN HORMIGÓN}

La toma de muestras debe de realizarse de manera cuidadosa, escogiendo aquellas que sean representativas. Se aconseja que las muestras a analizar procedan del interior del hormigón, ya que las partes más externas del mismo pueden estar más carbonatadas, obteniéndose resultados no representativos.

Las técnicas más adecuadas para confirmar la existencia o no de cemento aluminoso hidratado en un hormigón son: el análisis químico por vía húmeda y la difracción de rayos $X$ (DRX), siendo el análisis térmico-diferencial y gravimétrico (ATD/TG) una buena ayuda cuando los resultados de DRX no son concluyentes.

Otras técnicas complementarias orientativas y de rápida ejecución son: el método de la oxina, y el color.

\subsection{Análisis Químico: Determinación del Módulo Silícico}

Como es sabido la composición química de un cemento aluminoso difiere de modo importante de la de un cemento portland ordinario. De ahí, que sus módulos silíceos [e.g. $\mathrm{Ms}=\% \mathrm{SiO}_{2} /\left(\% \mathrm{Al}_{2} \mathrm{O}_{3}+\right.$ $\left.+\% \mathrm{Fe}_{2} \mathrm{O}_{3}\right)$ ] sean muy diferentes. El Ms de un cemento aluminoso suele oscilar entre 0,2-0,05 frente a valores aproximadamente de 1,7-4 en un cemento portland. Así pues, conociendo el valor de Ms en el hormigón problema se puede concluir si es de cemento aluminoso o no.

En la Tabla I se recoge la composición química media de los cementos portland y aluminoso. De dicha tabla se desprende que además de la diferencia en contenido en $\mathrm{Al}_{2} \mathrm{O}_{3}$, hay también distintos contenidos en $\mathrm{SiO}_{2}$ y $\mathrm{Fe}_{2} \mathrm{O}_{3}$ en ambos cementos.

\section{INTRODUCTION}

When coonfronted with a anomaly encountered in a concrete, the first question raised is to find out the type of binder which it contains. Nowadays, to solve this problem methods and techniques are being used, whose scope, reliability, and adequacy to the purpose sought are the subject of a polemic among technicians.

This paper reports on the most adequate techniques to identify the nature of the binder used in the making of a concrete and it suggests testing and interpretative methodologies.

\section{THE METHODS MOST ADEQUATE TO FIND OUT THE NATURE OF THE CEMENT (EITHER PORTLAND OR ALUMINOUS) USED IN A CONCRETE}

Sampling must be carried out carefully, choosing representative samples. It is advisable that the samples to be analized come from the inner part of the concrete, since the outer parts thereof can be more intensely carbonated, with which nonrepresentative results are obtained.

The most adequate techniques to confirm either the presence or the absence of a hydrated aluminous cement in a concrete are: the wet-method chemical analysis and $X$-ray diffraction (XRD); when the results of $X R D$ are not concluding, a good help may be found in differential-thermal and gravimetric analysis (DTATTG).

Other supplementary techniques, orientative and quick to perform are the oxine test and the color method.

\subsection{Chemical analysis: Determination of the silica modulus}

As it is well known, the chemical composition of an aluminous cement absolutely differs from that of an ordinary portland cement. Hence, that their silica moduli [i.e. Ms $=\% \mathrm{SiO}_{2} /\left(\% \mathrm{Al}_{2} \mathrm{O}_{3}+\right.$ $+\% \mathrm{Fe}_{2} \mathrm{O}_{3}$ )] be completely different. The Ms of an aluminous cement normally varies from 0.2-0.05, as againts values of about 1.7-4 in a portland cement. Therefore, if the Ms value in the problem concrete is known, it can be concluded whether it is made or not from aluminous cement.

Table I shows the average chemical composition of portland and aluminous cements. It follows from that Table that, in addition to the difference in $\mathrm{Al}_{2} \mathrm{O}_{3}$ contents, both cements also have different $\mathrm{SiO}_{2}$ and $\mathrm{Fe}_{2} \mathrm{O}_{3}$ contents. 
TABLA I TABLE I

Composición química media de cemento aluminoso y cemento portland (Average chemical composition of aluminous and portland cements)

\begin{tabular}{|l|c|c|}
\hline & Cemento aluminoso & Cemento portland \\
\hline $\mathrm{P} . \mathrm{F}$. & 0,80 & 1,8 \\
$\mathrm{SiO}_{2}$ & 1,4 & 22 \\
$\mathrm{Al}_{2} \mathrm{O}_{3}$ & 42,5 & 5,3 \\
$\mathrm{Fe}_{2} \mathrm{O}_{3}$ & 15 & 2,7 \\
$\mathrm{CaO}$ & 38 & 63 \\
$\mathrm{MgO}$ & 0,0 & 1,2 \\
$\mathrm{SO}$ & 0,0 & 3,0 \\
$\mathrm{FeO}$ & 2,1 & 0,0 \\
$\mathrm{CaO}$ libre & 0,0 & 0,9 \\
$\mathrm{M}_{\mathrm{s}}$ & 0,026 & 2,75 \\
\hline
\end{tabular}

Las determinaciones cuantitativas de los contenidos en $\mathrm{SiO}_{2}$ (sílice soluble en medio ácido), $\mathrm{Al}_{2} \mathrm{O}_{3}$ y $\mathrm{Fe}_{2} \mathrm{O}_{3}$, precisos para calcular el Ms, se hacen de acuerdo a la norma española UNE 80215, tras el ataque de una muestra representativa de hormigón en medio clorhídrico.

Los contenidos de $\mathrm{Si}, \mathrm{Al}$ y $\mathrm{Fe}$ en los líquidos, tras el ataque con ácido clorhídrico, pueden ser determinados también a través de diversas técnicas instrumentales, tales como la fluorescencia de rayos $X$, absorción atómica, plasma, fotometría de llama, colorimetría, etc.

La determinación únicamente del contenido de $\mathrm{Al}_{2} \mathrm{O}_{3}$ en dichos líquidos es utilizada, con frecuencia, para confirmar la presencia o no de cemento aluminoso en hormigones. Este método podría en ocasiones inducir a error si existiese alguna adición con altos contenidos en $\mathrm{Al}_{2} \mathrm{O}_{3}$ solubles en el medio ácido anteriormente mencionado. Tal es el caso de los cementos Tipo II, portland-escoria, o Tipo III, cemento de alto horno, que contienen escorias de alto horno en diferentes proporciones.

Es por todo ello por lo que se propone como método para determinar la naturaleza del cemento en un hormigón, la determinación de los contenidos en $\mathrm{Al}_{2} \mathrm{O}_{3}, \mathrm{SiO}_{2}$ y $\mathrm{Fe}_{2} \mathrm{O}_{3}$ solubles en medio ácido y el cálculo posterior de su módulo silícico. Este método es válido tanto para hormigones con áridos de naturaleza silícea como calcárea.

\subsection{Difracción de Rayos $X$}

La difracción de rayos $X(D R X)$ es la técnica idónea para saber si un hormigón es de cemento
The quantitative determinations of the $\mathrm{SiO}_{2}$ (acidmedium soluble silica), $\mathrm{Al}_{2} \mathrm{O}_{3}$ and $\mathrm{Fe}_{2} \mathrm{O}_{3}$ contents, required to calculate the $M s$, are conducted in conformance with the Spanish standard specification UNE 80215, after attacking a representative concrete sample with hydrochloric acid.

The Si, Al, and Fe contents in the liquids, after the attack with hydrochloric acid, may also be determined through certain instrumental techniques, such as $X$-ray fluorescence, atomic absorption, plasma, flame photometry, colorimetry, etc.

The determination of only the $\mathrm{Al}_{2} \mathrm{O}_{3}$ contents in said liquids is often used to confirm the presence of aluminous cement in concretes. This method could occasionally lead to error, in the event that some addition with high contents in $\mathrm{Al}_{2} \mathrm{O}_{3}$ soluble in the said acid medium does exist. Such is the case of the Type II cements, portland-slag, or type III, blast-furnace cement, which contain blastfurnace slag in different proportions.

For all of these reasons, the authors suggest, as a method to determine the nature of the cement in a concrete, the determination of the $\mathrm{Al}_{2} \mathrm{O}_{3}, \mathrm{SiO}_{2}$, and $\mathrm{Fe}_{2} \mathrm{O}_{3}$ contents soluble in an acid medium, and the subsequent calculation of its silica modulus. This method is valid for both concretes with siliceous and calcareous aggregates.

\subsection{X-ray diffraction}

$X$-ray diffraction (XRD) is the suitable technique to find out whether a concrete consists of aluminous 
aluminoso, ya que tanto sus compuestos anhidros como la mayor parte de sus productos de hidratación y carbonatación son policristalinos, lo que significa que al ser irradiados por un haz de rayos $X$, experimentan fenómenos de difracción, dando lugar a espectros característicos. Los únicos compuestos no detectados por DRX en esos hormigones son: el agua, la alúmina gel formada en las etapas iniciales de la hidratación, y la fase denominada $\mathrm{CO}_{2}$-hidrogranate generada durante el proceso de carbonatación del hidrato cúbico, $\mathrm{C}_{3} \mathrm{AH}_{6}$.

Los áridos, ya sean silíceos o calizos, son igualmente compuestos cristalinos, y por ser normalmente el componente mayoritario del hormigón, puede suceder que sus líneas características de difracción enmascaren aquéllas debidas a las fases del ligante (en este caso el cemento aluminoso). Es pues aconsejable que la muestra que se va a analizar por DRX, sea enriquecida en fase ligante. Ello se puede conseguir fracturando el hormigón problema y retirando por tamizado las partículas de árido.

Las fases que se pueden encontrar en un hormigón de cemento aluminoso totalmente hidratado son:
$\mathrm{CAH}_{10} \quad \mathrm{H}$. Hexagonales
$\mathrm{C}_{2} \mathrm{AH}_{8} \quad \mathrm{H}$. Hexagonales
$\mathrm{C}_{4} \mathrm{AH}_{13} \quad \mathrm{H}$. Hexagonales
$\mathrm{C}_{3} \mathrm{AH}_{6} \quad \mathrm{H}$. Cúbico
$\mathrm{AH}_{3} \quad$ Gibsita
$\mathrm{AH}_{3} \quad$ Bayerita
$\mathrm{AH}_{3} \quad$ Nordstrandita
$\mathrm{C}_{4} \mathrm{AH}_{11} \quad$ Monocarboaluminato cálcico hidratado
$\mathrm{C}_{2} \mathrm{ASH}_{8}$ Gelenita hidratada

En la Tabla II aparecen los principales compuestos hidratados que pueden encontrarse en una pasta de cemento aluminoso, así como sus líneas características de difracción y la intensidad relativa de las mismas. Las líneas marcadas son aquellas que, en principio, pueden servir para identificar esas fases cuando se encuentran en un hormigón aluminoso. Sin embargo, siempre es aconsejable confirmar la presencia de las fases con varias líneas características, ya que la existencia de otros compuestos cristalinos puede provocar interferencias o solapes con las líneas marcadas como idóneas para la identificación.

La fase hexagonal $\left(\mathrm{CAH}_{10}\right)$ y la cúbica $\left(\mathrm{C}_{3} \mathrm{AH}_{6}\right)$ son fácilmente identificables por DRX, cement, since both its anhydrous compounds and most of its hydration and carbonation products are polycrystallines, which means that, upon irradiation with a beam of $X$-rays, they experiment diffraction phenomena, resulting in characteristic spectra. The only compounds that are not detected by XRD in this type of concretes are: water, the alumina gel formed in the initial stages of hydration, and the phase called $\mathrm{CO}_{2}$. hydrogarnet, generated during the carbonation process of the cubic hydrate, $\mathrm{C}_{3} A \mathrm{H}_{6}$.

The aggregates, either siliceous or calcareous, are crystalline compounds too and since they usually are the major component of concrete, it is possible that their characteristic diffraction lines mask the lines pertaining to the binder (in this particular case, aluminous cement) phases. It is therefore advisable to enrich in the binder phase the sample to be XRD-analyzed. This can be made by breaking the problem concrete into pieces and withdrawing the aggregate particles by sieving.

The phases that can be encountered in an aluminous cement concrete are as follows:

$\begin{array}{ll}C_{A} H_{10} & \text { Hexagonal hydrates } \\ C_{2} A H_{8} & \text { Hexagonal hydrates } \\ C_{4} A H_{13} & \text { Hexagonal hydrates } \\ C_{3} A H_{6} & \text { Cubic hydrate } \\ A H_{3} & \text { Gybbsite }\end{array}$

$\mathrm{AH}_{3} \quad$ Bayerite

$\mathrm{AH}_{3} \quad$ Nordstrandite

$\mathrm{C}_{4} \mathrm{AH}_{11}$ Hydrated calcium monocarboaluminate

$\mathrm{C}_{2} \mathrm{ASH}_{8}$ Hydrated gehlenite

Table II shows the main hydrated compounds that may be found in an aluminous cement paste, as well as their characteristic diffraction lines and the relative intensity thereof. The marked lines are those which can serve in principle to identify the aforementioned phases when these are present in an aluminous concrete. However, it is always advisable to confirm the presence of the phases through several characteristic lines, since the existence of other crystalline compounds can cause either interferences or overlappings with the lines marked as apt for identification.

The hexagonal phase $\left(\mathrm{CAH}_{10}\right)$ and the cubic phase $\left(\mathrm{C}_{3} \mathrm{AH}_{6}\right)$ are easily identifiable by $X R D$, 
TABLA \| TABLE \|

Líneas de difracción características de los principales compuestos hidratados

de una pasta de cemento aluminoso

(Characteristic diffraction lines of the main hydrated compounds in an aluminous cement paste)

\begin{tabular}{|c|c|c|c|c|c|c|c|c|c|c|c|c|c|}
\hline \multicolumn{2}{|c|}{$\mathrm{CAH}_{10}$} & \multicolumn{2}{|c|}{$\mathrm{C}_{3} \mathrm{AH}_{6}$} & \multicolumn{2}{|c|}{$\mathrm{AH}_{3} \mathrm{~GB}$} & \multicolumn{2}{|c|}{$\mathrm{AH}_{3} \mathrm{BY}$} & \multicolumn{2}{|c|}{$\mathrm{C}_{2} \mathrm{AH}_{8}$} & \multicolumn{2}{|c|}{$C_{4} A_{C H} H_{11}$} & \multicolumn{2}{|c|}{$\mathrm{C}_{2} \mathrm{ASH}_{6}$} \\
\hline $2 \theta$ & $1 / I_{0}$ & $2 \theta$ & $1 / I_{0}$ & $2 \theta$ & $1 / I_{0}$ & $2 \theta$ & $I / I_{0}$ & $2 \theta$ & $1 / \sigma_{0}$ & $2 \theta$ & $\mid / / I_{0}$ & $2 \theta$ & $1 / I_{0}$ \\
\hline 6,2 & 90 & 17,2 & 90 & 18,2 & 100 & 18,8 & 90 & 8,2 & 100 & 11,7 & 100 & 7,1 & 100 \\
\hline 12,3 & 100 & 19,9 & 40 & 20,2 & 36 & 20,4 & 70 & 16,5 & 80 & 23,5 & 44 & 14,1 & 40 \\
\hline 18,7 & 10 & 26,5 & 54 & 20,5 & 18 & 27,8 & 30 & 20,9 & 10 & 31,3 & 30 & 18,0 & 10 \\
\hline 24,9 & 14 & 28,3 & 44 & 36,5 & 12 & 40,6 & 100 & 21,7 & 10 & 32,8 & 14 & 20,2 & 10 \\
\hline 35,0 & 12 & 31,8 & 80 & 37,6 & 16 & 53,1 & 40 & 22,5 & 10 & 35,5 & 18 & 21,2 & 70 \\
\hline 39,6 & 12 & 34,9 & 15 & 44,0 & 12 & 57,5 & 10 & 23,4 & 20 & 36,1 & 18 & 31,0 & 20 \\
\hline & & 36,4 & 30 & 50,4 & 10 & 63,8 & 12 & 24,8 & 60 & 36,8 & 18 & 34,3 & 20 \\
\hline & & 39,2 & 100 & & & 70,6 & 18 & 31,2 & 70 & 37,1 & 25 & 35,9 & 10 \\
\hline & & 44,3 & 94 & & & & & 32,2 & 20 & 38,4 & 20 & 36,2 & 10 \\
\hline & & 50,2 & 10 & & & & & 33,4 & 60 & 46,7 & 10 & 37,3 & 10 \\
\hline & & 52,4 & 40 & & & & & 35,3 & 70 & 50,0 & 12 & 37,9 & 20 \\
\hline & & 53,5 & 20 & & & & & 36,0 & 20 & 55,2 & 12 & 42,7 & 10 \\
\hline & & 54,5 & 50 & & & & & 36,6 & 10 & 55,6 & 12 & 44,8 & 10 \\
\hline & & 57,7 & 11 & & & & & 37,6 & 60 & 55,9 & 12 & 48,1 & 10 \\
\hline & & 58,7 & 13 & & & & & 40,2 & 30 & & & & \\
\hline & & & & & & & & 42,0 & 10 & & & & \\
\hline & & & & & & & & 43,0 & 50 & & & & \\
\hline
\end{tabular}

fundamentalmente por sus líneas situadas en $6,2^{\circ}$ y $12,3^{\circ}$ para el $\mathrm{CAH}_{10}$ y $17.3^{\circ}, 31.8^{\circ}, 39.2^{\circ}$ y $44.3^{\circ}$ para la fase cúbica. La existencia de una de estas fases o las dos confirmaría que el hormigón objeto de estudio contiene cemento aluminoso hidratado. Sin embargo, puede ocurrir que ninguna de estas fases aparezca en el difractograma (ya sea por conversión total de hidrato hexagonal a hidrato cúbico, y/o por carbonatación total). En tal caso, la fase cristalina que sí persistiría en la pasta y que sería válida para utilizarla como indicativa de la existencia de cemento aluminoso sería la gibbsita $\left(\mathrm{AH}_{3}\right)$, con sus líneas de difracción situadas en $18,2^{\circ}$ y $20,2^{\circ}$; o en su caso, la bayerita determinada principalmente por sus líneas situadas en $18,8^{\circ}$ y $40,6^{\circ}$.

Las fases mayoritarias del cemento portland anhidro son también compuestos cristalinos, sin embargo, su producto de hidratación mayoritario, el gel C-S-H, es de naturaleza amorfa. Las otras fases presentes en las pastas de cemento portland, es decir el $\mathrm{Ca}(\mathrm{OH})_{2}$ o portlandita, la ettringita y/o el monosulfoaluminato, sí son detectables por DRX. fundamentally by their lines located at $6.2^{\circ}$ and $12.3^{\circ}$ for $C A H_{10}$ and $17.3^{\circ}, 31.8^{\circ}, 39.2^{\circ}$, and $44.3^{\circ}$ for the cubic phase. The occurrence of one of these phases or of both of them would confirm that the concrete studied contains hydrated aluminous cement. However, it can happen that none of these phases appear in the diffraction pattern (by total conversion of the hexagonal hydrate into cubic hydrate and/or by total carbonation). In such a case, the crystalline phase that would certainly persist in the paste and that would serve as indicative of the presence of aluminous cement would be gibbsite $\left(\mathrm{AH}_{3}\right)$, with its diffraction lines located at $18.2^{\circ}$ and $20.2^{\circ}$, or else, bayerite, mainly determined by its lines located at $18.8^{\circ}$ and $40.6^{\circ}$.

The major phases in anhydrous cement also are crystalline compounds; however, its major hydration product, the C-S-H gel, is of an amorphous nature. The other phases present in portland cement pastes, i.e. $\mathrm{Ca}(\mathrm{OH})_{2}$ or portlandite, ettringite, and/or monosulfoaluminate, are certainly detectable by XRD. 
TABLA III TABLE III

Líneas de difracción características de los principales compuestos hidratados de una pasta de cemento portland.

(Characteristic diffraction lines of the main hydrated compounds in an aluminous cement paste)

\begin{tabular}{|c|c|c|c|c|c|}
\hline \multicolumn{2}{|c|}{$\mathrm{Ca}(\mathrm{OH})_{2}$ (portlandita) } & \multicolumn{2}{|c|}{ ettringita } & \multicolumn{2}{|c|}{$\begin{array}{c}\mathrm{Ca}_{4} \mathrm{al}_{2} \mathrm{SO}_{4} \cdot 12 \mathrm{H}_{2} \mathrm{O} \\
\text { (monosulfoaluminato) }\end{array}$} \\
\hline $2 \theta$ & $1 / I_{0}$ & $2 \theta$ & $1 / I_{0}$ & $2 \theta$ & $\mathrm{I} / \mathrm{I}_{0}$ \\
\hline 18,1 & 74 & 9,1 & 100 & 9,9 & 100 \\
\hline 28,7 & 23 & 10,0 & 14 & 19,9 & 90 \\
\hline 34,1 & 100 & 15,8 & 80 & 22,3 & 20 \\
\hline 47,1 & 42 & 17,8 & 25 & 31,0 & 10 \\
\hline 50,8 & 36 & 18,9 & 34 & 36,6 & 10 \\
\hline 54,3 & 21 & 22,9 & 50 & 37,1 & 20 \\
\hline 62,5 & 13 & 24,7 & 16 & 38,1 & 10 \\
\hline 64,2 & 13 & 25,6 & 30 & 40,3 & 30 \\
\hline 84,7 & 11 & 27,5 & 20 & 41,2 & 20 \\
\hline \multirow[t]{9}{*}{93,2} & 12 & 32,3 & 40 & 43,7 & 20 \\
\hline & & 33,2 & 14 & 47,7 & 10 \\
\hline & & 34,2 & 20 & 50,0 & 10 \\
\hline & & 35,0 & 44 & 51,1 & 10 \\
\hline & & 37,4 & 12 & 58,0 & 10 \\
\hline & & 44,4 & 20 & & \\
\hline & & 40,8 & 44 & & \\
\hline & & 41,3 & 10 & & \\
\hline & & 41,9 & 25 & & \\
\hline
\end{tabular}

En la Tabla III aparecen los principales compuestos hidratados (e identificables por DRX) que pueden encontrarse en una pasta de cemento portland, así como sus principales líneas de difracción con sus intensidades relativas. La presencia de todas o alguna de esas fases estaría confirmando la existencia de cemento portland en ese hormigón.

A través de DRX también es posible confirmar si hay mezcla de cemento aluminoso y cemento portland. La presencia de los compuestos hidratados típicos de un cemento portland, son fácilmente detectables por DRX. Algunos autores (1) han apuntado también que la presencia de $\mathrm{C}_{4} \mathrm{AH}_{13}$ (fase no habitual en una pasta de cemento aluminoso) indica que hay mezcla de ambos cementos, ya que dicha fase se forma en presencia de un exceso de $\mathrm{CH}$. Igualmente, se sabe que la detección de $\mathrm{C}_{2} \mathrm{ASH}_{8}$ (gelenita hidratada) por DRX permite concluir la existencia conjunta de ambos cementos.
Table III shows the major hydrated (and identifiable by XRD) compounds which can be found in a portland cement paste, as well as their main diffraction lines with their relative intensities. The presence of all or any of these phases would confirm the existence of portland cement in a concrete.

Through XRD, it is also possible to confirm whether a mixture of aluminous cement and portland cement is present. The presence of the typical hydrated compounds of a portland cement is easily detectable by XRD. Some aothors (1) have also suggested that the presence of $C_{4} A H_{13}$ (an unusual phase in an aluminous cement paste) shows that a mixture of both types of cement is present, since that phase is formed in the presence of excess $\mathrm{CH}$. It is likewise known that the detection of $\mathrm{C}_{2} A \mathrm{SH}_{8}$ (hydrated gehlenite) by $X R D$ permits to deduce the joint presence of both cements. 
En la práctica hay algunas ocasiones en las que las señales obtenidas en los difractogramas debidas a hidratos de cementos son tan débiles, que no es posible deducir con certeza la naturaleza del conglomerante. En tal caso la identificación se ha de apoyar en otra técnica.

\subsubsection{Carbonatos Cálcicos}

Capítulo aparte merece la interpretación que puede darse a la presencia de $\mathrm{CaCO}_{3}$ en sus diversas formas polimórficas (calcita, aragonito y vaterita) en las muestras de hormigón sometidas a estudio.

En la Tabla IV se recogen las líneas de difracción características de las tres formas polimórficas en las que se puede encontrar el carbonato cálcico.

Está plenamente demostrada la existencia de $\mathrm{CaCO}_{3}$ en el cemento aluminoso hidratado y carbonatado. La forma cristalina en la que aparece es función de determinadas condiciones, tales como humedad relativa, fase sometida a carbonatación, grado del mismo, etc.; aunque es relativamente frecuente la presencia de una
In the practice there are some occasions that the signals obtained from the diffractogramm due to hydrates of cements are very weak, and it is not possible to conclude the nature of binder. In these situations the identification could be help for other technique.

\subsubsection{Calcium carbonates}

Special consideration deserves the interpretation that may be given to the presence of $\mathrm{CaCO}_{3}$ in its different polymorphic forms (calcite, aragonite, and vaterite) in the concrete samples under study.

Table IV shows the diffraction lines characteristic of the three polymorphic forms in which calcium carbonate can occur.

The presence of $\mathrm{CaCO}_{3}$ in hydrated and carbonated aluminous cemen thas been fully demonstrated. The crystalline form in which it occurs depends upon certain conditions, such as the relative humidity, the phase subject to carbonation, the carbonation level degree, etc., although it is comparatively frequent the presence

TABLA IV TABLE IV

Líneas de difracción características de las tres formas polimórficas del $\mathrm{CaCO}_{3}$ (The diffraction lines characteristic of the three polymorphic forms of $\mathrm{CaCO}_{3}$ )

\begin{tabular}{|c|c|c|c|c|c|}
\hline \multicolumn{2}{|c|}{ Calcita } & \multicolumn{2}{|c|}{ Aragonito } & \multicolumn{2}{|c|}{ Vaterita } \\
\hline $2 \theta$ & $\mathrm{I} / \mathrm{I}_{0}$ & $2 \theta$ & $1 / I_{0}$ & $2 \theta$ & $1 / I_{0}$ \\
\hline 23,0 & 12 & 26,2 & 100 & 21,0 & 25 \\
\hline 29,4 & 100 & 27,2 & 56 & 24,9 & 60 \\
\hline 36,0 & 14 & 33,1 & 44 & 27,1 & 100 \\
\hline 39,4 & 18 & 36,1 & 28 & 32,8 & 90 \\
\hline 43,1 & 18 & 37,3 & 17 & 42,8 & 20 \\
\hline 47,5 & 17 & 37,9 & 32 & 43,8 & 60 \\
\hline 48,5 & 17 & 38,4 & 21 & 49,1 & 30 \\
\hline & & 38,6 & 18 & 50,1 & 70 \\
\hline & & 41,2 & 13 & 55,8 & 10 \\
\hline & & 42,9 & 23 & 62,8 & 10 \\
\hline & & 45,8 & 60 & 68,7 & 20 \\
\hline & & 48,3 & 28 & & \\
\hline & & 48,4 & 32 & & \\
\hline & & 50,2 & 25 & & \\
\hline & & 52,5 & 23 & & \\
\hline & & 53,0 & 14 & & \\
\hline
\end{tabular}


mezcla de las tres formas cristalinas en dichas muestras de cemento aluminoso.

Cualquiera de esas formas cristalinas, o mezcla de ellas, pueden presentarse también en hormigones de cemento portland carbonatado. La bibliografía respecto al tema es muy abundante.

En el ICCET, se hicieron al respecto diversas investigaciones algunas de las cuales se presentaron en el Simposio de Carbonatación de la RILEM, en Wesham (U.K.) en 1976 y fueron publicados en la revista MATERIALES DE CONSTRUCCIÓN $(2,3)$. En esos trabajos se demuestra la formación de vaterita, aragonito y calcita en cementos portland carbonatados anhidros e hidratados.

Takemoto y Saiki (4) dicen textualmente "E $\mathrm{CaCO}_{3}$ en cementos (portland) aireados en ambiente de alta humedad (>90\%) se encuentra en forma de calcita y "si la humedad relativa es baja (40-50\%) está en forma de aragonito".

Krsywblucka-Aurow (5) realizaron un estudio sobre hormigones de cemento portland, concluyendo que el $\mathrm{CaCO}_{3}$ aparece como vaterita, calcita y aragonito, dependiendo de la temperatura de curado de las muestras.

Takagi y col. (6) indican, así mismo, que en hormigones de cemento portland hay formación simultánea de vaterita y aragonito.

Lach $(7,8)$ ha estudiado extensamente diversos aspectos de la carbonatación de cementos portland, y entre otras cosas afirma que:

- Con humedades relativas muy altas se encuentra aragonito, que posteriormente evoluciona hacia calcita.

- La carbonatación de la "tobermorita de 11 Å", se puede esquematizar:

$$
\begin{gathered}
11 \AA \text { tober } \rightarrow \text { vaterita }+\mathrm{SiO}_{2} \mathrm{gel} \rightarrow \\
\rightarrow \text { calcita }+\mathrm{SiO}_{2} \mathrm{gel}+ \\
+ \text { aragonito }+\mathrm{SiO}_{2} \text { gel }
\end{gathered}
$$

Matousek y Miskousky (9) indican que los procesos de la carbonatación del gel C-S-H dan vaterita, aragonito y calcita en distintas proporciones dependiendo del porcentaje de $\mathrm{CO}_{2}$ y de la humedad relativa.

M. Venuat (10) dice textualmente en un estudio sobre carbonatación de hormigones portland: "... el $\mathrm{CaCO}_{3}$ producido es una mezcla de vaterita, calcita y aragonito". Continua en el mismo trabajo "... en los cementos portland los principales constituyentes hidratados se carbonatan como sigue: of a mixture of the three crystalline forms in the aforesaid samples of aluminous cement.

Any of these crystalline forms -or mixtures thereof - can also occur in carbonated portland cement concretes. The literature on this subject is abundant.

At the ICCET, some work was conducted which was submitted to the RILEM Sumposium on Carbonation, held in Wesham (U.K.) in 1976. The corresponding papers were published in MATERIALES DE CONSTRUCCIÓN $(2,3)$. The formation of vaterite, aragonite and calcite in carbonated portlano cements, anhydrous and hydrated, is demonstrated in those works.

Takemoto and Saiki (4) state textually that " $\mathrm{CaCO}_{3}$, in aerated portland cements in a high humidity environment (>90\%), occurs in the form of calcite and, if relative humidity is low (40-50\%), in the form of aragonite".

Krsywblucka-Aurow (5) have conducted a study on portland cement concretes, and reached the conclusion that $\mathrm{CaCO}_{3}$ occurs as vaterite, calcite, and aragonite, depending on the curing temperature of the samples.

Takagi et al. (6) also point out that there is a simultaneous formation of vaterite and aragonite in portland cement concretes.

Lach $(7,8)$ has widely studied various aspects of the carbonation of portland cement and states, among other things, that:

- For very high relative humidities, aragonite occurs, which subsequently evolves to calcite;

- The carbonation of " $11 \AA$ tobermorite" can be outlined as follows:

$$
\begin{gathered}
11 \AA \text { tober. } \rightarrow \text { vaterite }+\mathrm{SiO}_{2} \mathrm{gel} \rightarrow \\
\rightarrow \text { calcite }+\mathrm{SiO}_{2} \mathrm{gel}+ \\
+ \text { aragonite }+\mathrm{SiO}_{2} \mathrm{gel}
\end{gathered}
$$

Matousek and Miskousky (9) indicate that the carbonation processes of the $\mathrm{C}-\mathrm{S}-\mathrm{H}$ gel result in vaterite aragonite and calcite, in various proportions which depend upon the $\mathrm{CO}_{2}$ percentage and the relative humidity.

M. Venuat (10) says textually: "... the $\mathrm{CaCO}_{3}$ produced is a mixture of vaterite, calcite and aragonite...". He goes is the same work: "... in portland cements the main hidrated constituents are carbonated as follows: 


$$
\mathrm{Ca}(\mathrm{OH})_{2}+\mathrm{CO}_{2} \rightarrow \mathrm{CaCO}_{3}+\mathrm{H}_{2} \mathrm{O}
$$

$\mathrm{Gel} \mathrm{C-S-H}+\mathrm{CO}_{2} \rightarrow$ Gel de silice + vaterita (o aragonito más raramente); la vaterita se transforma en calcita

Sulfoaluminato de calcio $+\mathrm{CO}_{2} \rightarrow$ aragonito + + sulfato de calcio"

Finalmente, D. M. Roy (11) afirma que la mayor parte del $\mathrm{CO}_{2}$ absorbido forma vaterita, aragonito o calcita.

La existencia de vaterita, aragonito y calcita (fases establecidas fácilmente por DRX) en las pastas de cemento, de ninguna manera, con los conocimientos actuales, puede ser utilizada para constatar la presencia de cemento aluminoso en las mismas. Para ello tendría que comprobarse simultáneamente la existencia de algún compuesto de $\mathrm{Al}$ (especialmente el $\mathrm{Al}(\mathrm{OH})_{3}$ en alguna de sus formas).

\section{MÉTODOS COMPLEMENTARIOS}

\subsection{Análisis térmico-diferencial y termogravimétrico (ATD/TG) $\left(^{\star}\right)$}

Esta técnica, pese a no poder ser considerada en la práctica como una técnica idónea de identificación de la naturaleza del conglomerante de un hormigón, sí es complementaria a la Difracción de Rayos X, pudiendo ser en algunos casos, dada su gran sensibilidad, una técnica de apoyo $e$ incluso concluyente cuando los resultados de DRX no lo son.

El análisis térmico-diferencial (ATD) da idea de las transformaciones físico-químicas que tienen lugar en una sustancia determinada y las temperaturas a las que dichas transformaciones ocurren.

Toda transformación físico-química que sufre una sustancia, lleva implícito un intercambio de calor con el medio que le rodea. Si el medio cede calor, la transformación es de tipo endotérmico; pero si es la sustancia la que cede el calor, la transformación es exotérmica.

Por otra parte, la termogravimetría (TG/DTG) estudia las variaciones de peso que experimenta una sustancia en función de la temperatura.

Estas técnicas pueden ser utilizadas para la identificación de los componentes mineralógicos

(*) En este mismo número de MATERIALES DE CONSTRUCCIÓN, se incluye un extenso trabajo de BUSHNELL, WATSON y SHARP sobre el tema.

$$
\mathrm{Ca}(\mathrm{OH})_{2}+\mathrm{CO}_{2} \rightarrow \mathrm{CaCO}_{3}+\mathrm{H}_{2} \mathrm{O}
$$

tobermorite $\mathrm{CSH}+\mathrm{CO}_{2} \rightarrow$ Silica gel + + vaterite (or rarely aragonite); vaterite is tranformed to calcite

Calcium sulfoaluminato $+\mathrm{CO}_{2} \rightarrow$ aragonite + + calcium sulfate

Finally, D.M. Roy (11) states that most of the absorbed $\mathrm{CO}_{2}$ forms vaterite, aragonite or calcite.

The presence of vaterite, aragonite, and calcite (phases which can easily be established by XRD) in cement pastes can in no way, in the present state of the art, be used to state the presence of aluminous cement in such pastes. For this purpose, the presence of some Al compound [specially, $\mathrm{Al}(\mathrm{OH})_{3}$ in any of its forms] should have to be simultaneously established.

\section{COMPLEMENTARY METHODS}

\subsection{Differential-thermal analysis and gravimetric analysis (DTA/TG) $\left(^{*}\right)$}

This technique, although it cannot be considered as an adequate technique to identify the nature of the binder in a concrete, is supplementary to $X$-Ray Diffraction, and can be in some cases a support technique and even concluding, when $X R D$ results are not.

Differential-thermal analysis gives an idea of the physico-chemical transformations taking place in a determined substance and the temperatures at which such transformations occur.

Every physico-chemical transformation experienced by a substance implies a heat exchange with the surroungding environment. When the environment gives up heat, the transformation is of an endothermal type, but, if is the substance that gives up heat, the transformation is exothermal.

On the other hand, thermogravimetry (TG/DTG) studies the weight variations experienced by a substance in terms of temperature.

These techniques can be used to identify the mineralogical components of a material, as well

(*) In this same review (MATERIALES DE CONSTRUCCIÓN) an extense paper of BUSHNELL, WATSON and SHARP study this field. 
de un material, así como para determinar las reacciones producidas en los mismos por efecto de la temperatura.

Las reacciones o transformaciones físico-químicas que pueden ocurrir, son tales como,

deshidrataciones, deshidroxilaciones, oxidaciones, descomposiciones, cambios polimórficos, fusiones, etc. Los resultados obtenidos por ATD pueden ser apoyados por los estudios termogravimétricos simultáneos, en donde la variación de masa es monitorizada en función de la temperatura.

Las pastas de cemento (ya sea cemento aluminoso o cemento portland) poseen, además del agua de humedad, una importante cantidad de agua que forma parte de la estructura de las fases hidratadas, ya sea en forma de hidróxido o de agua de cristalización o constitución.

La deshidratación de dichas fases se produce a temperatura constante, siendo también constante la cantidad de agua perdida, así como la cantidad de calor intercambiado por unidad de masa.

En la Tabla $V$ se muestran las temperaturas de las señales de las curvas de ATD debidas a deshidrataciones y descarbonataciones de los componentes existentes en el cemento aluminoso hidratado. Este cuadro está tomado de la Monografía del Instituto Eduardo Torroja "Estudio de las transformaciones del cemento aluminoso hidratado. Influencia del $\mathrm{CO}_{2}$, temperatura, humedad y adición de caliza en polvo" (12).

En el caso de pastas de cemento portland, su constituyente mayoritario, el gel C-S-H, pierde agua de modo continuo desde $110^{\circ} \mathrm{C}$ hasta aproximadamente $600^{\circ} \mathrm{C}$, de modo que no hay señal singular que le caracterice. Por su parte, el $\mathrm{Ca}(\mathrm{OH})_{2}$, el monosulfoaluminato y la ettringita, pierden agua a temperatura constante dando en ATD una señal endotérmica característica. Naturalmente, si el hormigón de cemento portland está totalmente carbonatado, la señal debida a la deshidroxilación del $\mathrm{Ca}(\mathrm{OH})_{2}$ no se detectará.

En la Tabla VI se presenta un listado con las señales endotérmicas más significativas que habrá que buscar en la curva de análisis térmico para una correcta caracterización de la naturaleza del conglomerante de un hormigón, ya sea aluminoso o portland.

De lo expuesto, se puede concluir que la pasta hidratada de cemento aluminoso presenta señales térmicas características a temperaturas diferentes de las exhibidas por el cemento portland.

Un procedimiento adecuado para diferenciar el tipo de conglomerante en un hormigón sería pues hacer un ATD/TG sobre una muestra de hormigón enriquecida en pasta de cemento, mantenida as to determine the reactions produced in such components by the effect of temperature.

The reactions or physico-chemical transformations which can take place are such as dehydrations, dehydroxilations, oxidations, decompositions, polymorphic changes, meltings, etc. The results obtained by DTA can be supported by simultaneous thermogravimetric studies, where the mass variation is monitored versus the temperature.

Cement (either aluminous cement or portland cement) pastes contain, in addition to humidity water, an important amount of water which forms part of the structure of the hydrated phases, in the form of hydroxide or of crystallization or constitution water.

The dehydration of said phases takes place at a constant temperature, and the amount of water lost is also constant, as well as the heat amount exchanged per mass unit.

Table $V$ shows the temperatures of the signals in the DTA curves, due to the dehydrations and decarbonations of the components present in hydrated aluminous cement. That Table has been borrowed from a Monograph of the Instituto Eduardo Torroja "Study of the transformations of hydrated aluminous cement. The influence of $\mathrm{CO}_{2}$, temperature, humidity, and addition of powdered limestone" (12).

In the case of portland cement pastes, their major constituent, the C-S-H gel, loses water in a continuous manner from $110^{\circ} \mathrm{C}$ to about $600^{\circ} \mathrm{C}$, so that there is no singular signal characterizing it. On the other hand, $\mathrm{Ca}(\mathrm{OH})_{2}$, monosulfoaluminate, and ettringite lose water at constant temperature, giving a characteristic endothermal signal in the DTA. Naturally, if the portland cement concrete is completely carbonated, the signal due to the dehydroxilation of $\mathrm{Ca}(\mathrm{OH})_{2}$ shall not be detected.

Table VI shows a listing with the most significative endothermal signals which must be sought in the thermal analysis curve to correctly characterize the nature of a concrete binder, either aluminous or portland.

It can be concluded from the foregoing that hydrated aluminous cement paste shows characteristic thermal signals at temperatures different from those shown by portland cement.

Therefore, and adequate procedure to differentiate the nature of the binder in a concrete would be to make a DTA/TG on a concrete sample enriched in cement paste, maintaining the sample at $60^{\circ} \mathrm{C}$ 
TABLA V TABLE V

Temperaturas, según la bibliografía, de los picos de deshidratación y descarbonatación de los componentes existentes en el cemento aluminoso hidratado

(Temperatures, according the literature, of the signals of deshydration and decarbonations of the components present in hydrated aluminous cement)

\begin{tabular}{|c|c|c|}
\hline Componentes & Temperatura del pico $\left({ }^{\circ} \mathrm{C}\right)$ & Referencias bibliográficas \\
\hline $\mathrm{CAH}_{10}$ & $\begin{array}{l}110^{\circ}+160^{\circ} \\
157^{\circ} \\
140^{\circ}-170^{\circ} \\
155^{\circ}+285^{\circ}\end{array}$ & $\begin{array}{l}13 \text { y } 14 \\
15 \\
16 \text { y } 17 \\
18\end{array}$ \\
\hline $\mathrm{C}_{2} \mathrm{AH}_{3}$ & $\begin{array}{l}280^{\circ} \\
290^{\circ} \\
140^{\circ} \\
130^{\circ}-190^{\circ}\end{array}$ & $\begin{array}{l}19 \\
16 \text { y } 17 \\
20 \\
21\end{array}$ \\
\hline $\mathrm{C}_{3} \mathrm{AH}_{3}$ & $\begin{array}{l}325^{\circ} \\
330^{\circ} \\
315^{\circ}\end{array}$ & $\begin{array}{l}15 \\
22 \\
23\end{array}$ \\
\hline $\mathrm{Al}(\mathrm{OH})_{3} \mathrm{Gel}$ de Alúmina & $\begin{array}{l}100^{\circ}-140^{\circ} \\
127^{\circ}\end{array}$ & $\begin{array}{l}24 \\
15\end{array}$ \\
\hline$\alpha$-Al $(\mathrm{OH})_{3}$ bayerita & $\begin{array}{l}312^{\circ}\left(-15^{\circ} \text { inferior agibsita }\right) \\
\left(+250^{\circ}+525^{\circ}\right) \text { pequeños y eventuales }\end{array}$ & 24 \\
\hline$\gamma-\mathrm{Al}(\mathrm{OH})_{3}$ gibsita & $\begin{array}{l}320^{\circ} \\
\left(+250^{\circ}+525^{\circ}\right) \text { pequeños y eventuales } \\
310^{\circ}\end{array}$ & $\begin{array}{l}24 \\
15\end{array}$ \\
\hline $\begin{array}{l}\alpha-\mathrm{AlO}_{3} \mathrm{OH} \text { diásporo } \\
\gamma-\mathrm{AlO}_{3} \mathrm{OH} \text { boehmita }\end{array}$ & $510^{\circ}-580^{\circ}$ & 24 \\
\hline $\mathrm{C}_{4} \mathrm{~A}_{3} \mathrm{H}_{3}$ & $-750^{\circ}$ & 25 \\
\hline Alto carboaluminato $\mathrm{CC}_{4} \mathrm{AH}_{32}$ & $\begin{array}{l}135^{\circ} \text { deshidratación } \\
910^{\circ} \text { (con irregularidades) } \\
\text { descarbonatación }\end{array}$ & $\begin{array}{l}26 \\
26\end{array}$ \\
\hline Bajo carboaluminato $\mathrm{CC}_{4} \mathrm{AH}_{12}$ & $\begin{array}{l}220^{\circ} \text { deshidratación } \\
800^{\circ}+895^{\circ} \text { dos endotérmicos } \\
\text { separados por breve recuperación }\end{array}$ & 26 \\
\hline Carbonato cálcico $\mathrm{CO}_{3} \mathrm{Ca}$ & $\begin{array}{l}750^{\circ}-960^{\circ} \\
\text { desde }>750^{\circ} \text { hasta } 960^{\circ}\end{array}$ & $\begin{array}{l}\text { Numerosas referencias } \\
(12,27,28,29)\end{array}$ \\
\hline $\mathrm{C}_{12} \mathrm{~A}_{2} 2,5 \mathrm{CO}_{3} \mathrm{Ca}$ & Más alta temperatura que $\mathrm{CO}_{3} \mathrm{Ca}$ & 30 \\
\hline
\end{tabular}


TABLA VI TABLE VI

Listado con señales endotérmicas más significativas de compuestos característicos

de pastas de cemento portland y aluminoso

(Listing with the most significative endothermal signals of characteristic compounds in pastes of portland and aluminous cements)

\begin{tabular}{|l|c|}
\hline \multicolumn{1}{|c|}{ Compuesto } & Temperatura \\
\hline $\mathrm{CA} \cdot \mathrm{H}_{10}$ & $155^{\circ}-160^{\circ} \mathrm{C}$ \\
$\mathrm{C}_{3} \mathrm{~A} \cdot \mathrm{H}_{6}$ & $315^{\circ}-340^{\circ} \mathrm{C}$ \\
$\mathrm{AH} \mathrm{H}_{3}(\mathrm{Gibsita}$ o Bayerita) & $285^{\circ}-310^{\circ} \mathrm{C}$ \\
$\mathrm{Ca}(\mathrm{OH})_{2}$ & $520^{\circ}-560^{\circ} \mathrm{C}$ \\
$\mathrm{C}_{3} \mathrm{~A} \cdot 3 \mathrm{CaSO} \mathrm{S}_{4} \cdot 32 \mathrm{H}_{2} \mathrm{O}$ Trisulfoaluminato cálcico hidratado (ETTRINGITA) & $145^{\circ}-150^{\circ} \mathrm{C}$ \\
$\mathrm{C}_{3} \mathrm{~A} \cdot \mathrm{CaSO}$ & $12 \mathrm{H}_{2} \mathrm{O}$ (Monosulfoaluminato cálcico hidratado) \\
\hline
\end{tabular}

durante 48 horas a $60^{\circ} \mathrm{C}$. Este secado permitiría eliminar la mayor parte del agua de humedad de la muestra y convertiría, en caso de tratarse de un hormigón de cemento aluminoso, todo el hidrato hexagonal que todavía restase en hidrato cúbico, con el correspondiente incremento de la señal de $\mathrm{C}_{3} \mathrm{AH}_{6}$ y $\mathrm{AH}_{3}$ en el termograma. Caso de tratarse de cemento portland este tratamiento no afectaría a las señales del termograma.

\subsection{Método de la oxina}

Un método complementario que se utiliza habitualmente para confirmar la presencia de cemento aluminoso, es el conocido como método de la oxina (31). Es un ensayo rápido y cualitativo basado en la gran cantidad de aluminio que se disuelve al tratar una pasta de cemento aluminoso con una disolución de hidróxido sódico diluido. Este aluminio es posteriormente detectado por el tratamiento, en medio ácido, con oxina para formar un precipitado de color amarillo (oxinato de aluminio). En iguales condiciones, la disolución de aluminio a partir de pastas de cemento portland es prácticamente nula, por lo que no se produciría precipitado alguno. Ello es previsiblemente debido a la presencia de $\mathrm{Ca}(\mathrm{OH})_{2}$, ya que esta fase disminuye de modo muy importante la solubilidad del aluminio en medios fuertemente básicos.

La reacción de formación del oxinato de aluminio puede verse perturbada $e$ inducir a una interpretación errónea, si el hormigón de cemento portland está carbonatado. Toda vez que en este caso no hay $\mathrm{Ca}(\mathrm{OH})_{2}$ disponible para inhibir la solubilidad del aluminio, y por tanto el método de la oxina da falso positivo. Se ha comprobado en ensayos de laboratorio que una cantidad superior al $50 \%$ en peso de $\mathrm{CaO}$ respecto al contenido de cemento aluminoso anhidro puede alterar el test dando falso negativo, lo que demuestra la hipótesis antes mencionada. during 48 hours. This drying would permit to eliminate most of the humidity water from the sample and, in the case of an aluminous cement concrete, it would convert the whole of the hexagonal hydrate still remaining into the cubic hydrate, with the corresponding increase in the $\mathrm{C}_{3} \mathrm{AH}_{6}$ and $\mathrm{AH}_{3}$ in the thermogram. In the case of portland cement, this treatment would not effect the signals in the thermogram.

\subsection{The oxine test}

A supplementary method generally used to confirm the presence of aluminous cement is that known by the name of the oxine test (31). This is a quick qualitative test based on the great amount of aluminum which is dissolved when an aluminous cement paste is treated with a diluted sodium hydroxide solution. This aluminum is subsequently detected when treated -in an acid medium with oxine to form a precipitate of yellow color (aluminum oxinate). Under the same conditions, the dissolution of aluminum from portland cement pastes is practically null and not precipitate is formed. This is foreseably due to the presence of $\mathrm{Ca}(\mathrm{OH})_{2}$, since this phase very intensely diminishes the solubility of aluminum in strongly basic media.

The reaction of formation of the aluminum oxinate can be disturbed and induce to wrong conclusions if the portland cement concrete is carbonated. In that case, there is no $\mathrm{Ca}(\mathrm{OH})_{2}$ available to inhibit the solubility of aluminum, and therefore the oxine test gives a wrong positive result. It has been verified in laboratory tests that an amount of $\mathrm{CaO}$ of over $50 \%$ weight with respect to the anhydrous aluminous cement can alter the test and give a wrong negative result, which demonstrates the above assumption. 
Este mismo efecto inhibidor del $\mathrm{Ca}^{2+}$ se ha podido comprobar en otras experimentaciones, en las que se tenía una mezcla de yeso y cemento aluminoso. Cuando el contenido en yeso era superior al $10 \%$ en peso, se produce la insolubilización del aluminio, dando, por consiguiente, reacción negativa al método de la oxina. Este comportamiento no se ha observado en experiencias realizadas sobre el mismo cemento pero con sulfato sódico.

En definitiva, el método de la oxina debe utilizarse tan sólo con carácter orientativo y de ninguna manera como resolutivo.

Un técnico o analista experimentado puede diferenciar entre los distintos precipitados que se pueden presentar; en cualquier caso, la formación abundante de un precipitado amarillo no establece definitivamente la presencia de cemento aluminoso, y debe completarse el estudio con análisis químicos y/o DRX.

\subsection{Color}

El color que tiene el hormigón también puede ser un buen indicador de la presencia de cemento aluminoso. Su color, tanto en el interior como en el exterior, es negruzco y difiere bastante del color gris característico del cemento portland. Esto, sin embargo, debe ser tomado con precaución ya que ciertas adiciones activas (como cenizas volantes y humo de sílice) dan una coloración más oscura a los hormigones elaborados con cemento portland.

Cuando se produce la transformación de hidrato hexagonal a hidrato cúbico se origina también un cambio en el color de la pasta adquiriendo los hormigones una tonalidad marrón (similar al chocolate). En un principio este color puede ser orientativo de la presencia de cemento aluminoso, aunque hay que tomarlo con precaución ya que ese color también puede ser debido a los productos generados en la corrosión de las armaduras y/o la presencia de determinados áridos.
This very same inhibiting effect of the $\mathrm{Ca}^{2+}$ ion coul be verified in other experiments with a mixture fo gypsum and aluminous cement. When the gypsum contents was over $10 \%$, the aluminum is insolubilized, resulting therefore in a negative reaction to the oxine test. This behavior has not been observed in experiments conducted with the same cement, but with sodium sulfate.

In the final analysis, the oxine test must be only used in an orientative manner and in no way as conclusive.

An experienced technician or analyst can differentiate among the various precipitates that can be obtained; in any case, an abundant formation of a yellow precipitate does not definitively establish the presence of aluminous cement, and the study should be complemented with chemical and XRD analyses.

\subsection{Color}

The color shown by the concrete can also be a good indicator of the presence of aluminous cement. Its color, both in the inside and on the outside, is blackish and considerably differs from the characteristic grey color of portland cement. This fact, however, must be taken cautiously into account, since certain active additives (such as flyash and silica fume) impart a darker coloration to concretes made from portland cement.

When a hexagonal hydrate is transformed into a cubic hydrate, the paste also undergoes a change of color, the concrete acquiring a brown shade (chocolate-like). This coloring can be orientative in principle, althouogh it must be taken with care, since this color can also be due to the products formed in the corrosion of the reinforcement and/or the presence of certain aggregates.

\section{REFERENCIAS REFERENCES}

(1) B. F. COTTIN: $7 . .^{2}$ Int. Cong. on the Chem. of Cem., VIII, V-113 (1980).

(2) D. GASPAR TEBAR, C. DEL OLMO RODRÍGUEZ y T. VÁZQUEZ MORENO: Materiales de Construcción, n. ${ }^{\circledR}$ 161, (1976)

(3) D. GASPAR TEBAR, M. MUÑOZ y T. VÁZQUEZ MORENO: Materiales de Construcción, n. ${ }^{\circledR}$ 168, (1977).

(4) TAKEMOTO, K. y SAIKI, Y.: Gypsum and Lime, n. 981 , p. 4, (1966).

(5) R. KRSYWBLUCKA-LAUROW: Simposio Int. Carbonation of Concrete. RILEM-FULMER (U.K.) (1976)

(6) S. TAKagI, G. YAmagueHI y SaIto, Y.: Rev. 30 the Gen. Meet. Cem. Ass. Japan. p. 44, (1975).

(7) V. LACH: Simp. Int. RILEM. Paris (1971). 
(8) V. LACH: Simposio Int. sobre "Carbonation of Concrete". RILEM-FULMER (U.K.) (1976).

(9) M. MATOUSEK y J. MISKOVSKY: Referido por V. LACH en (8).

(10) VENUAT: Ann. ITBTP, n.9 364, p. 42 (1976).

(11) D. M. ROY: $8 .^{9}$ Cong. Int. de la Q. de los Cementos. V.I., p. 373. Río de Janeiro (1986).

(12) T. VÁZQUEZ, F. TRIVIÑO, A. RUIZ DE GAUNA: Monografía del IETCC n. 334, pág. 27-28. Madrid (1976).

(13) S. UEDA: Rev. Mat. Const., n. ${ }^{2} 154$, págs. 55-60 (1970).

(14) J. VOLANT: Rev. Mat. Const. n. $633-634$, p. 270 (1968).

(15) H. G. MIDGLEY: Trans. Br. Cer. SOC. V. 66, p. 161 (1976).

(16) Z. V. TUlovskaya y E. E. Segalova: Z. M. Prinkl. Khim. 37, 267 (1964).

(17) V. S. RAmachandRan: Appl. of ATD in Cem. Chem. - Chem. Publis. Comp. Inc. N. Y. p. 210 (1969).

(18) S. J. SCHNEIDER: J. Am. Cer. Soc. p. 184 Ab. (1959).

(19) P. MITSCHEDLOV: Petrosian Silik. Tech. V. 9, 556 (1958).

(20) M. REY: Silic Ind. V. 22, 553 (1957).

(21) R. FELDMAN y K. S. RAMACHANDRAN: J. Am. Cer. Soc., V. 49, 268 (1966).

(22) H. G. KALOUSEK y J. A. ADAMS: J. Am. Conc. Inst. V. 23, p. 1.951 (1951).

(23) R. TURRIZIANI: L'Indust. Ital. del Cem., Agosto-Noviembre (1959).

(24) R. MACKENZIE: ATD of Clays Min. Soc. London. p. 311 (1957).

(25) V. S. RAMAchandRAN: Aplic. of ATD in Cem. Chem. P. 112 (1969).

(26) E. T. CARLSON y A. BERMAN: J. of Res. NBS, V. 64A, n. 4 (1960).

(27) V. S. RAMACHANDRAN: Aplic. of ATD in Cem. Chem. p. 97 (1969).

(28) K. T. GREENE: Proceed. 4. ${ }^{2}$ Int. Symp. Chem. Cement. p. 359, Washington (1960).

(29) P. LONGUET: Proceed. 5. ${ }^{2}$ Int. Symp. Chem. Cement. p. 239. Tokio (1968).

(30) F. COURTAULT: Rev. Mat., n. ${ }^{2} 569$, p. 573, Feb. Jun (1963).

(31) M. M. ROBERTS y S. A. M. T. JAFFREY: BRE Information, 15 - 15/74 (1975). 